\title{
Rastislav Němec
}

\section{Ockham k problematike „scientia“}

Tento článok sa snaží zamerat' na oblast' vedy a vedeckého dokazovania vo filozofii Viliama Ockhama. Bližšie chce analyzovat' jednotlivé, základné predpoklady vedeckého dôkazu, ako ho doctor invincibilis charakterizuje a poukázat' na odchýlky v porovnaní $\mathrm{s}$ tradičnými koncepciami, predovšetkým s aristotelovským poňatím vedy, jej predmetu a vedeckého dokazovania. Takáto Ockhamova definícia 
poukazuje na rôzne problémy - problém predmetu vedy, nutnosti a pravdivosti vedeckého tvrdenia a hlavne na otázky vedeckého dôkazu propter quid, ktorý je jediným spôsobom vedeckého napredovania. V článku sa navyše snažíme nastolit' otázku vzt'ahu scientia demonstrativa s ostatnými druhmi poznania, ktoré Ockham rozlišuje ako zdroje vedeckého poznania.

This article focuses on the conception of science and scientific knowledge in Ockham's philosophy. It analyzes some several basic presuppositions of the scientific arguments of doctor invincibilis and comparing traditional Aristotle's interpretation resumes some crucial departures from Aristotle's concept, object of science and scientific knowledge. Ockham's definition brings different questions - question of a ground of science, further problem of necessary and truth conditions of a scientific statements and - last but not least - question concerning demonstration propter quid, which is in Ockham's view the only way of scientific proceeding. Furthermore, it brings some light into the relation between scientia demonstrativa and other kinds of knowledges according to Ockham..

Medieval philosophy - Ockham - science - scientific demonstration - methodology

Na prvý pohl'ad sa zdá, že termín veda, vedecké bádanie sa začína rozvíjat' s novovekým kritickým myslením, s hl'adaním vedeckej, korektnej metódy bádania a so stredovekým myslením nemá nič spoločného. Toto zdanie môže byt' určite opodstatnené, hoci historická kontinuita niektorých vedecko-teoretických (a hlavne filozofických) problémov presahuje myslenie novoveku a siaha ovel'a d'alej do histórie. Preto skôr, než sa 
začneme zaoberat' otázkou „scientia“ u Ockhama, musíme si ozrejmit' niekol'ko skutočnosti.

V prvom rade si treba uvedomit', že pojem „scientia“ sa významovo neprekrýva s tým, čo chápeme ako „vedeckú teóriu“ $\mathrm{v}$ dnešných filozofickovedných dišputách. Dopúšt'ali by sme sa chyby, ak by sme chceli u stredovekých autorov objavovat' známky a semienka v novoveku založeného a v 20. storočí nanovo nastol'ovaného kontextu otázok a odpovedí. Podhubie týchto dnešných diskusií a zároveň aj otázky, ktoré nastol'ujú nové vedecké objavy nemôžu v tomto zmysle korešpondovat' s poňatím vedy v 13. či 14. storočíi. Naším zámerom v tomto článku je ozrejmit’ práve Ockhamovu víziu „scientia“ na základe jeho epistemologicko-logických predpokladov a zhodnotit' jej prínos k dnešnej vízii vedy respektíve koherenciu v rámci jeho systematického myslenia.

V druhom rade si treba uvedomit', že v stredoveku neexistovala len jedna „scientia“, existovali rôzne vedy a rozsahom tieto vedecké disciplíny zodpovedali skôr pojmu ,poznat"“ či skôr „vyznat' sa“, než dnešnému objektivity sa dožadujúcemu a falzifikačne napredujúcemu argumentovaniu ii. Ak hovoríme preto o „scientia“, máme na mysli systematický proces, ktorý je sprevádzaný skôr metodickými otázkami a odpoved’ami, z množstva ktorých sa vyberie tá najosvedčenejšia a vecne správna odpoved”iii. Počiatkom každej „scientia“ je preto formálne hl'adanie

\footnotetext{
i Podobné niečo môžeme vidiet' aj na pojme techné u Aristotela, ktoré bolo z hl'adiska rozsahu ovel'a komplexnejšie a v novoveku sa začalo významovo zužovat', či termín hylé, ktorý dnes v preklade „matéria“ môže evokovat’,fyzikálne“ chápanú matériu.

ii Porov. napríklad rozdelenie vied u Bonaventúru v diele Itinerium mentis in Deum II-III alebo v De reductione artium ad theologiam 2-5 alebo u Huga od sv. Viktora a jeho členenie vied v Didaskalione I, hlava II 751A.

iii Samozrejme, že táto inšpirácia pochádza z antiky od Platóna a Sokrata a hlbšie je zakorenená v literárnom žánri, ktorý dnes poznáme ako „quaestiones“, ktoré mali verejný charakter diskusie.
} 
možnosti a podmienok nášho poznania vôbec, ktoré je špecifické a vlastné na spôsob reflexie každému človeku.

\section{Aristotelovská tradícia „scientia““}

V tomto zmysle je jasné, že hlavným podnetom takéhoto diskurzu o vede bolo prevažne aristotelovské učenie o epistémé, ako ho Filozof podáva v Druhých analytikách a v 3. časti 6. knihy Nikomachovej Etiky ${ }^{\mathrm{i}}$. Veda v tomto zmysle súvisí s poznaním a podl'a Aristotela je to kognitívny habitus (héxis), habitus poznania spojený s poznaním (nutných) princípovii .

$\mathrm{Na}$ takéto poňatie vedy $\mathrm{v}$ zmysle evidentného poznania nutných právd získané na základe sylogizmu nadväzuje Ockham tým, že podl’a neho „scientia“ prebieha len vo vetách/jazyku. Aristoteles tvrdí, že predmetom vedy nemusí byt' vec alebo nejaká jej vlastnost', ale veta, ktorá je pravdivá - z čoho vyplýva, že existuje práve tol'ko vied, kol'ko jestvuje pravdivých viet ${ }^{\mathrm{iii}}$. Okrem toho sa vedy líšia čo do predmetu, preto je vied tol'ko, kol'ko je predmetov vedeckého skúmania.

\footnotetext{
${ }^{\mathrm{i}}$ Aristotelova definícia vedy ako habitu poznania nutných právd vyvolala vel'mi bujarú diskusiu v polovici 13. storočia medzi samotnými aristotelikmi, či je vedou aj teológia (utrum theologia scientia sit). Niektorí tvrdili, že teológia a filozofia si priamo protirečia a majú vlastný zdroj múdrosti, čo bolo odsúdené v r. 1277. Ockham sa vedeckost'ou teológie zaoberá sekundárne - čiže vidí skôr problém v tom, či l’udský intelekt môže evidentne poznat' pravdy, ktoré teológia predkladá a či sú evidentne pravdivé. V tomto zmysle sa vraciam k otázke, ako je možné poznanie a čo znamená poznat', ktorá je základnou otázkou „scientia“" ako takej.

ii Porov. Aristoteles 1962, I, 71b 16. a podobne Aristoteles 1937, VI, 3, 1139 b 31-35. Ockham sa pripája k tomuto názoru. Porov. Ockham, G., 2009, 453: „Poznat' znamená evidentné porozumenie pravde“ a inde: „Veda znamená evidentné uchopenie nutných právd..."

iii Aristoteles v Druhých analytikách tvrdí, že pod druhom, o vlastnosti ktorého ide v dokazujúcej vede treba chápat' subjekt (hypokeimenon) v zmysle vetného člena, lebo o ňom sa tieto vlastnosti ako predikáty vypovedajú. Ak teda jestvuje vo vede subjekt, na ktorom stavajú všetky vety danej vedy, potom ide o prvý subjekt, ktorý konštituuje jednotu takejto vedy. Porov. Honnefelder, L, 2009, 408.
} 
Ockham sa prikláňa $\mathrm{k}$ tomuto názoru, ked’ tvrdí, že „nepoznáme nič len to, čo je (...) zložené،i . „Zloženým““ (complexus) ${ }^{\text {ii }}$ sa myslí subjekt, ktorému sa niečo pridáva (predikát), z čoho vzniká veta. Subjekt poznanej vety a subjekt poznania sú preto identickí, nakol'ko subjekt je to, o čom niečo (v danej vede) vieme. Na rozdiel od Dunsa Scota, subjekt neobsahuje virtuálne poznanie všetkých záverov vedy, lebo subjekt jednej vety môže byt' subjektom aj inej vedy. Subjekt skrátka podla Ockhama neobsahuje habitus vedy, len predmet môže obsahovat' súhr poznania. Dokonca platí, že ak existujú viaceré závery s rozličnými subjektmi v prípade jednej vedy, potom aj veda môže mat' viac ako jeden subjekt, ktorý skúma.

Ockham chápe „predmet“ vedy ako „poznanú vetu“, kým „subjekt“ vedy je to, čo je logickým výrazom. Takýto názor nie je len dôsledným aristotelizmom, ale ako ešte uvidíme, pripája k Aristotelovmu dedičstvu niečo navyše. „Poznávat' len zložené“ znamená, že každý zložený termín (nielen pravdivý) môže byt' základom pre vedu (v tomto zmysle ide o súd). Veda totiž pracuje so správne zaradenými a navzájom nadväzujúcimi súdmiiii . Nie je ani tak dôležité, či sú pravdivé a či sú tieto súdy vyslovené alebo len napísané. $\mathrm{Z}$ tohto dôvodu je jasné, že „scientia“ je podl'a Ockhama „blízko“ každému človeku, nakol’ko je schopný vytvárat' súdy a komponovat' z nich úsudky. Čo z toho nevyplýva je, že záver bude každým človekom vždy z týchto premís správne a pravdivo vytvorený.

Otázkou v tomto zmysle zostáva: Z čoho takáto „scientia“ ako kritérium poznania potom vychádza? Čo je „vedeckým“ predmetom“? Všetko, čo je poznané: aj predmet našej skúsenosti (niečo skrz-naskrz

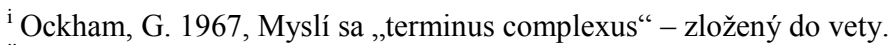

ii K zloženým (complexus) a nezloženým (incomplexus) termínom alebo výrazom pozri Ockham, G.1974, I, 3.

iii Porov. Ockham, G. 1967,.I, 5: „Semper scientia est respectu alicuius complexi vel complexorum..."
} 
kontingentné) $)^{\mathrm{i}}$ alebo niečo, čo len logicky konzistentne vyplýva z premís? Určite je v tomto bode zaujímavá otázka kontingencie a evidencie, ktorej sa dotkneme, nakol'ko Ockham v súlade s Tomášom a d’alšími autormi presadzuje možnost' intuitívneho poznania princípov.

Tieto otázky sa budeme snažit' zodpovedat' v našej štúdii. Pre správnost' a logickú nadväznost' by sme si hned' na začiatku uviedli krátku definíciu, ktorú Ockham uvádza v Komentári kAristotelovej Fyzike. Scientia je podla neho „evidentné poznanie nutného a pravdivého, ktoré môže byt' zapríčinené evidentným poznaním nutných premís zoradených podl'a sylogizmu... “ii Podl'a tejto definície vidíme, že veda sa ukazuje ako poznanie nutného a pravdivého na základe evidencie a sylogizmu. Bližšie sa však musíme pozastavit' pri jednotlivých obsahoch tejto definície.

\section{Vedecký súd je dubitabilis}

Spojenie vedy a istoty v stredoveku sa zdalo byt' samozrejmé, nakol'ko istota vedeckého súdu ostro konstrastovala s čisto plauzibilne pôsobiacou argumentáciou dialektiky. V tomto zmysle bude Ockhamov postoj ostrou kritikou lincolnského biskupa Grossatestu, ktorý tento model vedy a s ňou spojenej vedeckej istoty zastávaliii.

Skúsme si teda približit' Ockhamov názor. V prvom rade z jeho tvrdenia vyplýva (aspoň sa zdá), že veda musí stavat' na nutnosti, nie na

\footnotetext{
i Contingens znamená niečo, čo nie je ani nemožné, ani nutné. Porov. Ockham, G., 1985, 491: „, dicitur contingens, quod potest esse vel non esse et ita repugnat tam necessario quam impossibili.

ii Ockham, G. 1985, s. 6.

iii Grossatesta tvrdí, že človek by si nemal svoju dušu napíňat' tým, o čom panujú dohady a v čo sa dá verit', lež tým, čo je dokázatel'né a isté, lebo len stále a večné veci môžu ustálit' l'udský intelekt. Porov. Grossatesta, R., , s. 213.
} 
kontingencii. Súd, ktorý veda vynáša, teda musí mat' nárok na platnost', ale znamená to, že je nutne aj pravdivý?

Podl'a Ockhama musí takýto súd splńnat' niekol'ko podmienok. Súd môže byt' vedecký len v prípade, že je nutný, d’alej ked' je pochybný (dubitabilis) a ked’ je preukázaný (demonstrativus) na základe sylogizmu. Dubitabilis je preto, nakol'ko sa má v sylogizme overit' jeho pravdivost' alebo nepravdivost'. Ked' niekto vysloví súd, neznamená to hned', že tento súd je pravdivý, ale ked' ho pochopíme, zistíme, či je pravdivý, nepravdivý alebo sa dá o jeho pravdivosti pochybovat'. Preto aj pochybovanie podl'a Ockhama patrí k základným habitom poznania. Kým nie je naše poznanie isté, nemusí byt' hned' nepravdivé, ale je pochybné. A rovnako to, čo sa preukázalo ako isté, môže sa v istom okamihu ukázat' ako pochybné. Vedecký súd je nutný a z toho nevyplýva, že je všetkými evidentne nahliadnutý ako pravdivý, teda že je aktuálne ,scitur“, ale len že je „scibilis“. Toto „scibilis“ je podl’a Ockhama niečo, čo je otvorené názoru ostatných a čo možno ešte spochybnit'. Všetky nutné pravdy sú „scibilis“, z čoho vyplýva spomínaný fakt, že nemusia byt' ešte „scitur“. „Scibilis“ je habitus nášho poznania, akým sa dostávame k pravde - prostredníctvom pochybnosti a dôkazu/demonštrácie. Samozrejme, dôsledkom takéhoto zadefinovania vedy vzniká otázka niektorých vedeckých odvetví, ktoré nemôžu spochybňovat' poznanie, ktorého sa im dostalo - napr. teológia $\mathrm{v}$ tomto kontexte nie je zohl'adnená in se ako fides infusa ale ako teológia čisto budovaná človekom. ${ }^{\text {ii }}$

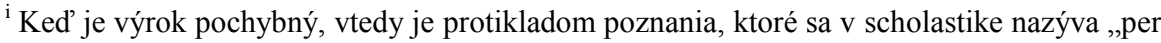
„per se nota“ - čiže poznanie na základe princípov. Pochybnost' vnáša do kvazivedeckého výroku otvorenost' voči možným korekciám a je pre vedca záväzná (dubitatio est obligatio). Pochybnost' tu vytvára istý novodobý predpoklad vedeckosti, nakol'ko sa pravda, pravdivost' obhajovala $\mathrm{v}$ dišpute. V tomto zmysle by sme mohli vidiet' medzi touto požiadavkou paralelu k Popperovskej falzifikácii.

ii K tomuto problému pozri napr. Leppin, V., 2005, s. 435-436. Porov. Moody, E., 1935, 280: „Ockham's analysis exhibits science as human activity..."
} 
Zastavme sa ešte na chvíl'u pri nutnosti vedeckého súdu. Vedecký súd musí byt' teda nutným súdom v závere. Naproti tomu $\mathrm{z}$ toho vyplýva, že kontingentný súd (a sem radí Ockham tzv. hypotetické, resp. modálne výrokyi), ktorý sa svojím obsahom a referenciou dotýka kontingentných vecí, nestálych vecí, nemôže mat' charakter vedeckého poznania - k čomu sa ešte vrátime. Treba však povedat’, že „nutný súd“ neznamená to isté, čo „vždy platný, pravdivý súd“. To, čo je v danom prípadne nutné, je pravdivost' výroku, nie ,vecný stav“ toho, čo označuje. V tomto zmysle Ockham rozlišuje medzi „propositio de necessario“ - ontologickým rozmerom - ako výrokom vzt’ahujúcim sa k ontologickému záväzku a „propositio necessaria“ ako vždy nutnej propozícii, ktorej pravdivost' nemusí byt' nutná.

\section{„Scientia“" vyplývajúca z kontingencie}

Vrát’me sa na chvíl'u k druhému problému - problému kontingencie ako zdroju poznania. Ockham sa od scholastikov líši aj v tomto názore. Nazdáva sa, že „niektoré princípy môžeme poznat’ na základe skúsenosti،“ii Podl'a Ockhama jednak intelekt uchopuje predmet, ale aj predstavivost' (virtus phantastica) po tom, čo zmysly uchopia zmyslový predmet, si môže ten istý zmyslový predmet predstavit', hoci odlišným spôsobom. Ak napríklad pocítime na svojom tele teplo, intelekt je schopný poznat', že ide o teplo na základe „skúsenosti tepla“, z čoho pre intelekt vyplýva axióma,

\footnotetext{
i Ockham rozlišuje medzi asertorickým výrokom (propositio de inesse), kedy je predikát priradený subjektu bez modu, od modálnych výrokov: ,propositio modalis est illa, in qua ponitur modus". Porov. SL II, OPh I, 242.

${ }^{\text {ii }}$ Porov. Ockham, V., 2009, SL III-2, 10. In: Antológia Patristika a scholastika, s. 455. Alebo inde: $S L$ III, 2, 4. OPh I, 511: ,quaedam autem principia prima non sunt per se nota, sed tantum per experientiam, quia possunt dubitari, sed tamen per experientiam fiunt nota..."
} 
že ak niečo teplé priblížime $\mathrm{k}$ niečomu neteplému, nutne to teplé musí zohriat', čiže axióma: „Každé teplo zohrieva““i. Takýto princíp je podl’a Ockhama získaný skúsenostne, a preto podl’a neho platí, že stačí nám pri niektorých princípoch poznania poznávat' skúsenostne a môžeme objavit' nové „nutné pravdy“. Rovnako stačí evidentné poznanie toho-ktorého singulárneho, kontingentného výroku - ako napríklad „toto teplo zohrieva“ a nie je nutné, aby sme poznali iné singulárne výroky na dosiahnutie evidentného poznania. Toto všetko však platí v prípade najnižšieho druhu ${ }^{i i}$. Ak ide o niečo všeobecnejšie než najnižší druh, potom sa aspoň väčšinou vyžaduje, aby sme poznali singulárny výrok o akomkol'vek druhu, ktorý je obsiahnutý v tomto všeobecnom. Jednoducho povedané: Ockham tvrdí, že $\mathrm{v}$ prípade niečoho všeobecnejšieho môžeme toto všeobecné chápat' ekvivokým spôsobom, k čomu sú nevyhnutné viaceré jednotlivé súdy. Ak chceme povedat' o niečom kontingentnom pravdivý, evidentný výrok, potrebujeme viac podobných aktov (poznania), potrebujeme viac singulárnych výrokov, čiže potrebujeme viac „skúseností“, aby sme mohli opísat' dostatočne predmet prostredníctvom výrokov. Ockham uvádza príklad bylinky. Ak vieme, že v jednom prípade táto bylinka pomohla, musíme získat' viac podobných prípadov, aby sme vedeli, čo je to tak naozaj a bylinka má liečivý účinok ${ }^{\mathrm{iii}}$. Tu nachádzame prvý moment, poukazuje na vzt’ah „scientia“ k bežnej skúsenosti, z ktorej čerpá princípy.

Spomínané dva druhy uchopovania predmetu - na základe virtus phantastica a aktu intelektu - predstavujú o Ockhama dva vzájomne sa

\footnotetext{
${ }^{\text {i }}$ Porov. Ockham, G., 1974, 455.

ii Ide o tzv. species specialissima, ktorú Ockham chápe ako najnižší druh nazeraný intuitívne intuitívne SL I $21 \mathrm{OPh}$ I, 71: ,species specialissima est intentio non habens speciem sub se..."

iii Porov. Ockham, G., 2009, SL III-2, 10, s. 456.
} 
doplńajúce druhy poznania ${ }^{i}$. Ak chceme vediet', aká tá daná vec je a či vôbec existuje, jedinou možnost'ou je rovina zmyslového vnímania, ktorú Ockham nazýva intuitívnym poznaním. Ak povieme: „Vonku sneži“, jediným spôsobom, ako sa o tom môžeme presvedčit’ je „notitia visiva““ii čiže zmyslové (optické) vnímanie, ktoré nás presvedčí o tom, či je to tak alebo nie. Ak vidíme, čo daná vec je, môžeme zároveň vediet', či vôbec jestvuje. Toto je jeho druhý moment, ktorým Ockham potvrdzuje, že princípy vedy a vedeckého bádania sa musia čerpat' aj z bežnej skúsenosti.

Takéto poznanie je intuitívne, bezprostredné uchopovanie veci (simplex apprehensio rei), ktorým dosahujeme evidentné ${ }^{\text {iii, }}$, čiže vedecké poznanie nielen toho, aká vec je, ale striktné poznanie vecného stavu, ktorý sa môže zhodovat' s obsahom výroku alebo nemusí. Takéto poznanie sa týka veci, ktorá je konkrétna, aktuálne prítomná a zakúšaná, čiže jestvuje, čo má vel’mi dôležitú úlohu pre Ockhamov singularizmus a čo ho odlišuje od intuície D. Scota. Napr. poznanie niečoho horúceho môže vychádzat' zo skúsenosti, ked' priložíme ruku $\mathrm{k}$ horúcemu hrncu. Toto popálenie nás privedie nielen k poznatku, že „niečo horúce nás môže vždy popálit““, ale aj k d’alšiemu evidentnému poznaniu, že „to horúce“ skutočne jestvuje. Od jednoduchého intuitívneho poznania sme sa dostali $\mathrm{k}$ intelektuálnemu intuitívnemu poznaniu, ktoré nahliada pravdivost' intuitívne poznaných právd.

Abstraktívne poznanie naopak podla Ockhama vyplýva z toho, že vec prestala byt' alebo nie je prítomná a nie je možné v tomto zmysle

\footnotetext{
i Ockham prevzal teito dva druhy poznania: intuitívne a abstraktívne od svojho učitel'a Dunsa Scota, ktoré predstavil v Ordinatio II., dist. 3, part 2, kv. 2, no v niektorých momentoch - hlavne v otázke princípu individuácie sa navzájom rozchádzajú. Ockham načrtáva svoju teóriu intuitívneho a abstraktívneho poznania napr. v Reportatio, kniha II, kv. 12 a 13.

${ }^{i i}$ Nazýva tento princíp „principium experientiae“ - princíp skúsenosti.

iii Tu sa natíska slovesný základ latinského e-videre (evidentia) a latinského videre - vidiet', ktorý Ockham spája, tento fakt však nižšie o niečo spresníme.
} 
povedat', či existuje alebo nie. Ak uvažujeme o niečom minulom, ked' si na niečo spomíname, spomíname si na obrazy (species) a zážitky jednotlivých vecí, ktoré sa nám ukotvili v spomienkach, čiže nepoznávame bezprostredne. Toto je jedna strana a funkcia notitio abstractiva - ked' intelekt odhliada od existencie, respektíve neexistencie danej veci ako aj od iných jej akcidentov. (OTh I 31). Ak uvažujeme všeobecnejšie a spájame podobné veci, uvažujeme $\mathrm{v}$ pojmoch $\mathrm{s}$ väčšou mierou abstrakcie, postupne sa vzd'al'ujeme od toho, čo sa nazýva „obsah termínu“ a vd’aka tomu poznávame aj kontingentné pravdy ako evidentné. Táto notitio abstractiva má však aj druhú stránku, ked' si intelekt vytvára univerzáliu, ktorou označuje mnohé veci toho istého druhu. Abstraktívne poznanie vzniká len vd'aka tomuto singulárnemu intuitívnemu nazeraniu jednotlivých vecí. Z týchto jednotlivých skúseností sa odhliada od priestorového a časového určenia a intelekt si vytvára prirodzené „znaky“ vecí - čiže pojmy, v Ockhamovom zmysle univerzálie. Abstraktívne poznanie nie je nič iné ako poznanie univerzálií. Čo je ale univerzália podl'a Ockhama? V tradícii Avicennu a Ockhama niečo čo zastupuje viaceré veci toho istého druhu. Preto možno povedat', že pojem človek je univerzáliou, nakol'ko označuje viaceré singulárne veci toho istého druhu ${ }^{\mathrm{i}}$ a bol získaný abstrakciou (preto abstraktívne poznanie) singulárnej veci.

O abstraktnom poznaní hovoríme aj v prípade sylogizmu skladajúceho sa $\mathrm{z}$ dvoch evidentných nutných premís a jedného záveru. Intelekt musí uznat' obe premisy ako evidentné, aby mohol byt' evidentný a nutný aj záver. Navyše intelekt priamo nahliada všetky časti (termini) každého súdu ako pravdivé alebo nepravdivé, inak nevie pochopit' jeho význam.

\footnotetext{
${ }^{\mathrm{i}}$ Porov. Ockham, G., 1974, 12. Porov. Avicenna 1980, V, 1., s. 237 n.
} 


\section{Rôzne podoby evidencie podl'a Ockhama}

Na základe vyššie povedaného môžeme zhrnút', že existujú tri formy (vedeckej) evidencie, ako ich Ockham chápe. V prvom rade ide o samo sebou známe, evidentné poznatky (tzv. per se notum). Toto poznanie sa týka priamo nahliadnutých právd, axióm, ktoré sa môžu stat' základom ostatných (odvodených) pravidiel. Napríklad princíp identity, ked' niečo vieme, že je a aké to je, nemôže to byt' iné. Na druhom mieste stojí evidencia, ktorá sa získava odvodením poznania per se notum, čiže priamo vyplýva z tvrdení, ktoré sú per se notum. Napríklad: A=Á sa môže stat' základom d’alšej axiómy, ktorá $\mathrm{z}$ nej priamo vyplýva $\mathrm{A} \neq \mathrm{B}$. Takáto evidencia nie je podla Ockhama o nič menšia a o nič spornejšia v porovnaní s prvou. Rovnako ani tretia: evidencia, o ktorej sme sa už zmieňovali - získaná na základe bezprostrednej zmyslovej skúsenosti, čiže intuitívneho poznania môže byt rovnako adekvátnym zdrojom vedeckej pravdy (aliquid verum complexum) ${ }^{\mathrm{i}}$.

Evidencia tvorí kvalitu súdu. Hoci sme skonštatovali, že existujú rôzne „kvality“ tejto evidencie, jedinou jej podmienkou podla Ockhama je to, aby si tvrdenia zoradené $\mathrm{v}$ jednom sylogizme, o ktorom sa vie, že je pravdivý, neprotirečili. Táto neprotirečivost' ukazuje, že jednak evidencia získaná zo skúsenosti a jednak evidencia získaná per se, obsahujú to istétii Napr. veta: „Človek sa smeje“ je kontingentná, veta „človek (nakol'ko je človekom) sa môže smiat" je nevyhnutná. Tu vidíme, že oba druhy

\footnotetext{
${ }^{\text {i }}$ Porov. Ockham, G., 1967, 21-23. Rovnako porov. Ockham, G., 1974, 5-10: „,...unde sciendum est quod sensu apprehendente aliquod sensibile potest virtus phantastica idem imaginari, et non solum phantastica ed etiam intellectus potest idem apprehendere, quo apprehenso potest intellectus aliquas propositiones contingentes evidenter cognoscere..."

ii Porov. Beckmann, P. J., 1981, „Scientia proprie dicta“. s. 645.
} 
výrokov sa vzájomne zhodujú. Evidentné je teda niečo, čo predpokladá nemožnost' kontradiktorického opakui.

V tomto zmysle vidíme, že kým u Scota je evidencia zárukou nutnosti, u Ockhama je pre vedecký súd evidencia priam dôležitejšia ako nutnost' (čiže stále trvajúca platnost' nejakého vedeckého výroku), lebo aj z kontingentného výroku, kontingentných vecí na základe empirickej skúsenosti je možné vytušit' princípy, s ktorými,,scientia“ pracuje ako so samozrejmými nástrojmi. Aj $\mathrm{v}$ tomto zmysle Ockham korektne a konzistentne tvrdí, že ako je „scientia“ blízko každému človeku, tak je evidencia empiricky a intuitívne nahliadnutel'ná nielen tomu, kto sa venuje v striktnom zmysle vedeckému bádaniu, ale l’ubovol'ne každému, kto je schopný dospiet' $\mathrm{k}$ rovnakému súdu vzhl’adom na príslušný stav veci.

\section{„Scientia“ získaná prostredníctvom dôkazu}

Ockham teda tvrdí, že „scientia“ pracuje s logicky správnymi úsudkami zoradenými do sylogizmu ${ }^{\text {ii. }} \mathrm{Z}$ tohto by teda mohlo vyplývat', že hoci evidencia je získaná a blízka každému človeku, ešte nie každý človek vie správne usudzovat' na záver z dvoch jemu zrejmých tvrdení. Skúsme sa teda zastavit' pri predpokladoch, vlastnostiach a definícii takéhoto dôkazu, ako ho doctor invincibilis definuje.

\footnotetext{
${ }^{\text {i }}$ Porov. Ockham, G., 1974,.18-19.

ii Poznanie na základe dôkazu Aristoteles charakterizuje ako poznanie nevyhnutného spojenia dosiahnutého na základe stredného termínu. Porov. Aristoteles, 1962, 675 a, 1215. Stredným termínom (medium) Ockham chápe to, čo nám prináša poznanie - teda nielen „terminus medius“, ale čokol'vek, čo spresňuje naše poznanie. Ockham preto chápe „medium“ širšie. Navyše, rozlišuje viaceré druhy sylogizmov: jeden z nich je dokazujúci (demonstrativus) a tým sa budeme bližšie zaoberat'. Ostatné (napr. syllogismus topicus a improbabilis SL III-1 c. 1) sú menej striktné dôkazy, čím zjemňuje aristotelovskú tézu o sylogizme.
} 
Samozrejmým predpokladom vedeckého dôkazu je poznat', čo je subjekt, že jestvuje a poznat' vlastnosti toho, čo znamená meno danej vlastnosti v propozícii. Jednoduchým dôvodom toho je fakt, že „aby dôkaz mohol nastat', je nevyhnutné, aby sme poznali premisy“ - čiže tú premisu, v ktorej sa vypovedá niečo o subjekte a navyše, aby to, čo obsahuje, nebolo len potenciálnei. Treba ale povedat', že Ockham chápe vedecký dôkaz priamo ako takýto sylogizmus zložený z dvoch premís a jedného záveru. Každý sylogizmus obsahuje členy, ktoré musia byt' evidentné, aby bol celý dôkaz platný a mal výpovednú hodnotu: väčší termín, menší termín a stredný termín. Toto je najhlavnejšia podmienka sylogizmu Definícia dôkazu, ako ju Ockham predkladá teda znie: „demonstratio (est) syllogismus faciens scire ecii. $\mathrm{Z}$ tohto tvrdenia vyplýva jasný fakt, že ak je niečo predmetom vedeckého dokazovania, nemôže to byt' poznatok ,,per se notum", ale záver tohto argumentovania môže byt' pochybnýiii.

Ďalším predpokladom podl'a Ockhama je fakt, že sylogizmus, ktorý má byt' platný, musí podliehat princípu „dictum de omni, dictum de nullo“, čo znamená, že všetko, čo sa predikuje o indivíduu s istou prirodzenostou, predikuje sa o individuách s podobnou prirodzenost'ou a naopak - takýto predikát neprináleží čomukol'vek, čo je subjektomi ${ }^{\text {iv }}$.

\footnotetext{
${ }^{\text {i }}$ Porov. Ockham, G., SL III-2,3. OPh I, 508 Ak hovoríme o súcne v možnosti (ens in potentia), potom ho Ockham vylučuje ako kategóriu nárokujúcu si na kategorickú platnost', ked'že „takéto súcno nemôžeme chápat' tak, že niečo, čo síce nejestvuje, ale môže jestvovat' vo sfére vecí, je pravým súcnom a niečo iné, čo jestvuje vo sfére vecí, je taktiež súcnom“. Porov. OCKHAM, G.: Summa Logicae I, 38. OPh I 108. Napr. o tzv. chimére nie je možné vypovedat' nič nutné, nakol'ko nepatrí do sféry jestvujúcich vecí.

ii Porov. Ockham, G., 1974, 505: „Dico igitur quod omnes de demonstratione loquentes per hunc terminum demonstratio non intelligunt nisi syllogismum facientem scire..." a inde (17, $\mathrm{OPh}$ I, 532): „scire“ accipiendo pro notitia evidenti et certa, ubi necessarium sequitur ex propositionibus necessariis..."

iii „Omnis conclusio demonstrationis est dubitabilis, ita quod non est per se nota...“

iv Porov. Ockham, G., 1974, 363: „dici de omni quando nihil est sumere sub subiecto, quin de eo dicatur praedicatum.
} 
Princíp „dictum de nullo“ znamená, že subjektu všeobecným afirmatívnym výrokom denotujeme to, čo každému inému možnému subjektu, od ktorého sme odňali predikáti.

Takýto sylogizmus potom prináša a spôsobuje nové poznanie, poznanie niečoho nového (faciens scire). Pýtame sa: čo takýto sylogizmus prináša ako nový poznatok? Nutný záver, ktorý nutne vyplýva z premís. Ockham - a v tom spočíva vel'ký odklon od Aristotelovho učenia rozlišuje nutnost' $\mathrm{v}$ zmysle trvale platného (perpetuum) a na druhej strane neomylného záveru (conclusio) - v tomto zmysle sa nutnost' vzt'ahuje len na Boha a jeho výroky,. Ani naše výroky o Bohu nie sú nutné, pripisujeme mu predikáty, ktoré sú konotatívnymi termínmi ${ }^{\mathrm{ii}}$, tie nemajú stály význam a nemôžu byt' teda nutné. Nutný záver v druhom zmysle (a ten vyplýva z premís) je nutný, nakol'ko nemôže byt' nepravdivý (ide o logickú, nie ontologickú nutnost'). Nutnost'ou sa myslí vzt'ah subjektu a predikátu a je vlastná vedeckému dôkazu ako takému, hlavne čo sa záveru týka. Takýto záver má charakter dôkazu a pozostáva z afirmatívnych, kategorických a aktuálnych výrokov (tzv. výroky per se).

Takýto výrok môže byt' princípom (premisou) ostatných dôkazov, $\operatorname{argumentov}^{\text {iii. }}$ Z neho ako z princípu, ktorý má svoju nutnú platnost'

\footnotetext{
i Porov. Ockham, G., 1974, 363: „Dici de nullo est quando per eam denotatur quod de quocumque dicitur subiectum, quod ab eo removetur praedicatum.

ii Konotatívne termíny sú tie termíny, ktoré nie sú absolútnymi termínami. Absolútne termíny majú stály, pevný význam, ktorý sa nemení, naopak konotatívne sú tie, ktorých signifikát môže byt' aj primárny aj sekundárny. Ku konotatívnym termínom, ako ich Ockham definuje pozri SL I, 10. Porov. Klima, G.: „Being“. In: Lagerlund, H. (ed.) 2011, s. 157.

iii Porov. Ockham, G., 1974, 519. Aristoteles (Druhé analytiky kap. I, 90b) rozlišuje štyri otázky, na ktoré sa možno pýtat' a ktorým zodpovedá istý druh poznania. Medzi týmito otázkami je otázka spojenia vlastnosti a veci (quia est), otázka dôvodu (propter quid), otázka, či daná vec jestvuje (an sit) a štvrtá otázka jej prirodzenosti (quid est). Ockham pre demonštratívne dokazovanie vyberie dva druhy dôkazov bazírujúcich na dvoch poznaniach (propter quid a quia), nakol'ko zvyšné sa dajú zredukovat' práve na tieto dve.
} 
vyplýva pravdivost' tvrdení. Pravdivost' výrokov sa však dá potvrdit' dvojakým spôsobom.

\section{Dôkaz propter quid a dôkaz quia}

Ako sme si spomenuli, dvoch pravdivých premís je možné dedukovat' platný a pravdivý záver. Dôkaz musí však spočívat' na určitom predpoklade - napr. existencia veci a jej vlastnosti sú takýmto predpokladom, ktorý sa nedá dokázat'. Prvé princípy poznania sú preto podl'a Ockhama nedokázatel'né, hoci môžu slúžit' ako premisy. Povedat': „Sokrates je biely“ predpokladá, že vieme, že jestvuje/jestvoval.

Vedecký dôkaz naopak dokazuje niečo nové a niečo logicky nutné, nie to, z čoho sa vychádza. Preto je dedukovanie záveru podl'a Ockhama dokonalým dôkazom, pretože premisy vystihujú poznanie záveru skôr (prius), postrádajú akúkol'vek pochybnost' a z týchto premís sa dá objavit' príčina, prečo sa $\mathrm{v}$ skutočnosti niečo deje $\mathrm{e}^{\mathrm{ii}}$. Tento dôkaz sa v súlade $\mathrm{s}$ aristotelovskou tradíciou nazýva dôkaz propter quid. Je však zaujímavé, že dôkaz nemôže spočívat' len na analýze vlastností, ktoré daný výrok a termín už obsahuje. Dôvodom je, že takýto výrok/sylogizmus by nepriniesol nové poznanie. Naopak, tento dôkaz predpokladá niečo „,prv“ a preto je to deduktívny dôkaz čiže propter quid.

„Ked' napríklad vieme, že zatmenie Mesiaca vzniká tým, že Zem sa dostane do postavenia medzi Slnkom a Mesiacom, potom nevznikajú už nijaké d'alšie otázky, čo sa týka záveru 'Mesiac je zatmený'. Potom sa už

\footnotetext{
${ }^{\mathrm{i}}$ Toto je dôvod, pre ktorý Ockham vynecháva zvyšné dva druhy poznania - pozri poznámka poznámka predtým.

ii Porov. Ockham 1974, 359: ,Syllogismus demonstrativus est ille, in quo ex propositionibus necesariis evidenter notis potest adquiri prima notitia conclucionis“".
} 
nepýtame, či sa Mesiac stmieva a prečo sa stmieva“"i nakol’ko záver vyplýva z jednotlivých premís.

Ockham sa zamýšl'a, či v tomto príklade by sa dalo postupovat' aj opačne - čiže nepostupovat' z niečoho vopred známeho, ale usudzovat' na istý záver a dospiet' k istému poznaniu zo skúsenosti: „,...) Niekto iný vidí, že Mesiac sa stmieva, a nevie o tom, že Zem sa nachádza medzi Mesiacom a Slnkom, a usudzuje takto: 'Vždy, ked' sa Mesiac stmieva, Zem je v postavení medzi Slnkom a Mesiacom; Mesiac sa stmieva teraz, teda Zem sa nachádza medzi Mesiacom a Slnkom' ‘،ii Tento druh dôkazu nazýva nazýva dôkazom quia (aposteriórnym dôkazom) ${ }^{\mathrm{iii}}$. Rozdiel tohoto druhu dôkazu nie je len $\mathrm{v}$ jeho reverznom postupe, ale hlavne $\mathrm{v}$ tom, že sa ním ustanovuje spojenie medzi partikulárnym a všeobecným, pričom oboje je poznané induktívne.

Oba príklady ilustrujú rôzne druhy sylogizmov: prvý prezrádza poznanie zdôvodneného faktu, druhý prezrádza poznanie len samotného faktu. V prvom prípade poznanie záveru priamo závisí od predošlého poznania premisy ako príčiny, nie od predošlej skúsenosti záveru, ktorý sme nemuseli vediet' (nemuseli sme vediet' príčinu zatmenia Mesiaca). „Mesiac sa stmieva teraz“ vystihuje intuitívne uchopenú skutočnost', ktorá vychádza z konkrétnej skúsenosti. Nestanovuje však zdôvodnenie, prečo sa tak deje. Dôkaz propter quid však naopak vysvetl'uje, prečo sa tak deje: „Zatmenie Mesiaca vzniká tým, že Zme sa dostane do medzipostavenia medzi Slnkom a Mesiacom..."

Obidva druhy sú vierohodné a môžu byt' zdrojom d'alšieho poznania, dokonca zdrojom princípov. Podl’a Ockhama však len jeden

\footnotetext{
${ }^{\text {i }}$ Porov. Ockham, V., 2009, s. 458. Ide o príklad, ktorý uvádza aj Aristoteles, 1962, 6-18.

ii Porov. Ockham, V. 2009, s. 457.

iii Zdá sa, že Ockham ako prvý zaužíva používa tento aristotelovský „dôkaz quia“ a priori. Ritter, J., 1971, s. 464.
} 
z týchto dôkazov (niečo) dokazuje. Jeden dôkaz z premís sa dostáva k poznaniu záveru, druhý $\mathrm{z}$ rovnakých premís nedospeje k poznaniu záveru. Dôkaz quia je podl'a neho len dôkazom pre niekoho, nie dôkazom pre všetkých. Je dôkazom pre všetkých, nakol'ko sa týka mentálnych termínov a propozícií spoločných všetkým l'ud’om. Ockham sa teda pripája k názoru, že jediným zdrojom vedeckého poznania a zároveň spôsobom vedeckého dokazovania je dôkaz propter quid. ${ }^{\mathrm{i}}$ Ockham tak dovŕšuje kritiku Grossatestovho výkladu Aristotelových analytík, kde sa vyslovuje optimisticky o možnosti dôkazu v oblastí zatmenia Mesiaca.

Rozdiel medzi nimi vidno aj vo využítií týchto dôkazov. Zdalo by sa, že poznanie quia slúži ako premisa a poznanie propter quid ako záver. No v skutočnosti sa chce povedat', že sú akcidentálne voči sebe vo vzt’ahu subalternujúce versus subalternované poznanie - čiže princípy prvého poznania si osvojuje to druhé poznanie asi tak ako sa geometria „skonkrétňuje“ v optike a matematika vo fyzike

Najstriktnejším vedeckým dôkazom podl'a Ockhama je tzv. demonstratio potissima (najvyšší dôkaz), ktorá pracuje s dôkazmi propter quid. Ockham ho definuje takto: „Je to dôkaz propter quid, univerzálny voboch druhoch univerzálnosti (čiže čo sa týka času i vecí) a je afirmatívny. Z toho vyplýva, že patrí do prvej figúry (t. j., kde stredný termín je subjektom väčšej a predikátom menšej premisy) (...)prináša poznanie na základe príčiny a nakol'ko je afirmatívny, a je aj ostenzívny “iii.

i Samozrejme, Ockham zabúda na niektoré spomínané sylogizmy, ktoré by sme mohli nazvat' petitio principii a nie dôkaz propter quid, prinášajúci nové poznanie. Napr. výrok „Všetko, čo produkuje teplo, je teplé“, „Niečo teplé produkuje teplo“ čiže ,všetko, čo je teplé, produkuje teplo“. Už z premís vyplýva záver, čiže premisy poskytujú poznanie záveru, pritom sylogizmus neprináša nič nové.

${ }^{\text {ii }}$ Porov. Ockham, G. 1974, 538-548.

iii Porov. Ockham, G., 1967. 165. „,...) demonstratio potissima est illa quae est propter universalis utraque universalitate (...) et affirmativa; et ex hoc sequitur quod sit in prima figura eo ipso quod est propter quid; et quia est propter quid sequitur quod sit per causam; 
Týmto druhom dôkazu sa získava najistejšie poznanie veci, nakol'ko prvá figúra je afirmatívna a v tomto zmysle vystihuje vec, aká je prostredníctvom formálnej definície - quid rei. Touto definíciou a týmto dôkazom sa dospieva k esencii veci (propriissime dicta rei), čiže definícia vystihuje to, čo je (na) veci najvlastnejšie - napr. definícia trojuholníka ako geometrického obrazca s troma uhlami. Na základe nej môžeme skonštatovat', že uhly každého trojuholníka sa rovnajú dvom pravým uhlom, čo je tvrdenie, ktoré sa nedá popriet' a nevyhnutne vyplýva definície trojuholníka.

Termíny, ktoré sa nachádzajú v takejto demonstratio potissima, sú termíny druhej intencie ${ }^{\mathrm{ii}} \mathrm{V}$ striktnom zmysle do takéhoto dôkazu vstupujú len tzv. absolútne termíny, čiže termíny, ktorých signifikát nemôže byt' raz to, inokedy ono, ale vždy je rovnaký. Absolútne termíny sú nedefinovatel'né a suponujú podl'a Ockhama absolútne veci, čiže ich signifikát je extramentálny. Ockham tvrdí, že základ tejto striktnej metódy je niečo ,indemonstrabilis ${ }^{\text {“ }}$ - a priori, čiže stavia na princípoch v úzkom zmysle slova, ktoré sa nedajú dokázat', a rovnako sa táto metóda opiera o absolútne termíny, ktoré sú ,indefinibilis“, nakol'ko sú definované samotným predmetom (SL I 26. OPh I, 85). Výsledkom takéhoto

similiter (...) est ostensiva. Dôkaz quia nie je dôkazom len preto, že vychádza zo skúsenosti, ale aj vtedy, ked' je príčina vzdialená, neznáma. V tom prípade je sylogizmus na základe dôkazu quia negatívny a bude nutne tvorit’ druhú figúru. Napr. sylogizmus „Žiadne nezviera nedýcha“, „Rastlina je nezviera“ čiže „Rastlina nedýcha“ je toho príkladom (porov. SL III-2, 19). Síce sa dokazuje, že rastlina nedýcha, ale nevysvetl'uje sa, prečo je to tak.

${ }^{i} \mathrm{Na}$ rozdiel od materiálnej definície, ktorá sa týka vonkajších vlastností vecí, formálna vystihuje esenciálne a vnútorné princípy vecí. Formálna definícia zastupuje veci označené v definiendum, pričom predstavuje kvalitatívnu formu, respektíve finálnu príčinu. Napr. termín calefactive by sme mohli definovat' ako ,niečo, čo je schopné poňat' teplo“, ale táto definícia na druhej strane nie je presná.

ii Termíny druhej intencie (subjekt, predikát, univerzália, rod, druh) sú znakmi termínov prvej intencie, ktoré vznikli empirickým vnímaním a sú prirodzenými znakmi vecí. Termíny druhej intencie skúma a používa logika, kým metafyzika sa zaoberá termínmi prvej intencie. Porov. Ockham, 2009, SL I, 10. 
neskoršieho Ockhamovho chápania prezentovaného v SL je fakt, že najstriktnejší vedecký dôkaz spočíva v poznaní princípov a vyvodzovania poznania z týchto princípov, čo je jedným z troch zdrojov vedeckej istoty ${ }^{\mathrm{i}}$. Takéto poznanie, „scientia“, ktorá ním narába, je univerzálne (dici de omni) ${ }^{\mathrm{ii}}$ a nutné, nakol'ko nemôže byt' nepravdivé.

Problémom však je, že aj to najstriktnejšie vedecké dokazovanie pozostáva z termínov a tie sú znakmi vecí, čiže ide o vedecký výrok pozostávajúci aj z konotatívnych termínov a nehovorí sa o veciach ako takých. Ockham v tomto bode zabúda, že konotatívne termíny vstupujú $\mathrm{v}$ rovnakej miere aj do vedeckých argumentácií, z čoho by malo vyplývat', že nutné výroky a pravdy môžu platit' v závislosti od aktuálnej vedeckej deskripcie, prípadne platia len $\mathrm{v}$ určitom čase $t$. Podobne teda ani demonstratio potissima a žiadne iné vedecké tvrdenie nemôže si nárokovat' na pravdivost' a nutnost' v každom čase, hoci Ockham tvrdí, že áno. Ako sme mali možnost' vidiet', Ockham nepovažuje nutnost' vedeckého výroku za základ vedeckosti, ale dbá skôr o metodologickú presnost', logickú konzekventnost' a formálnu správnost' vedeckého výroku. V tomto zmysle je logicky správne tvrdenie aj vedecky dokázatel'né a vzbudzuje nádej, že je aj pravdivé.

\section{Záver:}

\footnotetext{
${ }^{\text {i }}$ Okrem Sv. Písma je zdrojom takejto istoty racionálny diskurz, ako sme ho práve uviedli a bezprostredná skúsenost'.

ii V Aristotelovom ponímaní je univerzálnost' vlastnost'ou výrokov per se. Ockham proti Aristotelovi a Robertovi Grossatestovi namieta, že takýchto univerzálnych a nutných výrokov per se je ovel’a menej a prináležia hlavne rovine vedeckého dokazovania.
} 
Ako sme mohli vidiet', Ockham na jednej strane siaha po aristotelovskej tradícii a interpretuje „scientia“ v pôvodnom zmysle „epistémé“, na druhej strane sa od Aristotela odkláňa a pri definovaní „scientia“ - zostáva pri logickej, formálnej, nie ontologickej nutnosti, čím čiastočne aj podrýva základy svojej metafyzickej doktríny singularizmu.

Vyššie spomenutý Ockhamov názor, že „scientia“ je sumár súdov, ktoré sú logicky usporiadané, prináša so sebou tiež isté dôsledky. V prvom rade neexistuje jedna jediná ,scientia“ - a tým ani jedna/dve pravdy - spor, ktorý vyústil v r. 1277 v odsúdení Aristotelovej doktríny a jeho žiakov ale pluralita vied - z hl'adiska vedeckého predmetu či z hl'adiska rôznych vedeckých súdov i metódy dokazovania tej ktorej vedyi. Filozofia nie je jedinou vedou a jediným, celostným nazeraním vecí, ale musí v tradícii R. Bacona komunikovat' s ostatnými vedami.

„Scientia“ ako ju Ockham predstavuje - napriek tomu, že vo svojom diele vyzdvihuje intuitívne poznanie pred abstraktívnym (singularizmus) - nestojí na principium experientiae, z ktorého vychádza ono poznanie konkrétne jestvujúcej veci, hoci aj tento zdroj poznania je vierohodný a slúži k d’alšiemu (vyššiemu) poznaniu. Scientia v tomto zmysle je neustále otvorený systém poznatkov, ktoré sa môžu ako východiskové poznanie menit', a tým sa môže menit' aj ich záver, systém, ktorý pracuje a logicky konštruuje to, čo ako svoje východisko intuitívne poňal v empirickej skúsenosti.

$\mathrm{Na}$ druhej strane Ockham prezentuje vedecký dôkaz ako sled logicky zoradených súdov, ktoré zo seba vyplývajú. „Scientia“ môže

\footnotetext{
${ }^{\mathrm{i}}$ Ockhamov postoj nenahráva ani filozofii ani teológii, ale vedám vôbec. Teológia už nie je jednotná a celostná s jednotlivými podoblast’ami filozofie ako u Bonaventúru, ale každá vedecká disciplína má iný predmet bádania: metafyzika teda predstavuje vedu iného poriadku ako etika či fyzika. Prvá skúma súcno, nakol'ko je, druhá l’udské konanie a jeho pravidlá, tretia pohyb a jeho zákonitosti. Ani čo sa týka roviny vedeckých súdov sa tieto vedy nezhodnú. Jediným spojivom týchto vied je nutné a isté poznanie princípov.
} 
počiatočne vychádzat' z kontingentných súdov a kontingentnej skutočnosti, z ktorej sa abstrahujú princípy slúžiace d’alej ako premisy sylogizmov. $\mathrm{Z}$ toho vyplýva, že Ockham prenáša Aristotelove nutné tvrdenia per se len do roviny vedeckého dokazovania. To znamená radikálny posun z roviny „propositio de necessario“, ktorá reflektuje ontológiu sveta k „propositio necessaria“" ako niečo logicky založenému. Najvyšším vedeckým poznaním je „scientia“ prostredníctvom dôkazu propter quid, lebo len ten prináša nové poznanie, hoci koniec koncov nie je možné dokázat', či daná vec jestvuje. Veda teda vie dokázat' isté pravdy, ktoré boli pochybné, ale nevie dokázat', či veci, ktorých sa pravda týka, sú skutočné. Rovnako z „demonstratio potissima“ vyplýva, že vedecký výrok ako taký už nie je „dubitabilis“, ako Ockham tvrdil vo svojej ranej tvorbe, ale predstavuje strictissime nutné poznanie, no pritom nie je isté, či dokazovaná pravda naozaj zodpovedá vecnému stavu- a len v tomto zmysle môžeme povedat', že je stále „dubitabilis“. Teda vedecké poznanie môže stavat’ na princípoch a rovnako môže týmto princípom vytvárat' hodnotovo úmerné tvrdenia. Avšak vo chvíli, ked’ je záver sylogizmu nahliadnutý len nepriamo (nie intuitívne), je stále do istej miery pochybný. Úlohou striktného vedeckého dokazovania potom je len rozlíšenie triedy istých propozícií, ktoré nie sú koextenzívne s triedou samo osebe evidentných, dokázatel'ných a intuitívne poznaných propozícií, od triedy približne pravdivých propozícií, ktoré naopak sú koextenzívne s triedou neevidentne pravdivých a hypoteticky nevyhnutných propozícií. Hlavným kritériom takéhoto rozlíšenia dvoch tried je logicko-epistemologická nevyhnutnost', s ktorou Ockham pracuje ako s kl'účom k celej svojej filozofii.

Ockhamov náčrt „scientia“ predstavuje skôr metodologický rozmer, než komplexnú hierarchiu vied. Vedy sa navzájom dajú hierarchicky zoradit' len akcidentálne, nie sú voči sebe vo vzt’ahu 
subalternans alebo subalternata ${ }^{i}$. To, čo sa dá dokázat' na základe dôkazu quia subalternovanou vedou, to isté môže dokázat' subalternujúca veda prostredníctvom dôkazu propter quid. Ockham takto ukazuje, aké sú podmienky vedeckého uvažovania a dokazovania a akým spôsobom možno dospiet' k „nutným“ tvrdeniam. Na druhej strane akousi vedou par excellence, ktorá čnie nad ostatnými vedami svojou všeobecnost'ou, je logika. Ide o špeciálnu vedu, nakol'ko všeobecné tvrdenia a metódy, ktoré používa, nutne musia používat' aj ostatné vedyii . Logika pomáha rozlišovat' pradivé a nepravdivé vety iii , je učitel'kou argumentácie a dáva nahliadnut' do významu reči (virtus sermonis), čím sa stáva základom pre dokonalé poznanie každej vedy ${ }^{\mathrm{iv}}$.Logika je však vedou, ktorá skúma termíny druhej intencie (racionálnou vedou), v čom vidiet' u Ockhama striktný rozpor v doceňovaní/preceňovaní hlavného nástroja vedeckosti. ${ }^{\mathrm{v}}$

\section{Zoznam skratiek:}

i Takýto rozdiel medzi vedami je daný akcidentálne a vyplýva z toho, že napr. optika využíva závery geometrie, tak ak fyzika závery matematiky. V tomto zmysle je prvá scientia subalternata a druhá scientia subalternans. Tzv. reálne vedy hovoria o veciach (res) a prvých intenciách suponujúcich veci - filozofia. Racionálne vedy (napr. logika!) pojednávajú o obsahoch duše (druhých intenciách suponujúcich termíny). Toto Ockhamovo rozdelenie vied sa zdá byt' dost' konfúzne.

ii Ockham, 1974, 751: Propter quod impossibile est aliquam scientiam naturalem vel moralem vel quamcumque aliam sine ista notitia perfecte habere...".

iii Porov. Ockham 1985, 6

iv Porov. Ockham, V., 2009, s. 422

${ }^{v}$ Porov. Ockham G., 1967, 275. Podobne Ockham 2009, s. 422. 
An. Post. - Druhé analytiky

OPh - Opera Philosophica

OTh - Opera Theologica

SL - Summa logicae

\section{Bibliografie:}

Aristoteles, 1962, Druhé analytiky. Prel. A. Kř́̌ž, Praha : ČAV.

Aristoteles, 1937, Etika Nikomachova. Prel. A. Kříž. Praha : Jan Laichter

Avicenna, 1980, Liber de philosophia prima V, 1. S. van Riet (ed.). Löwen - Leiden.

Ockham, W., 1974, Ockham's Theory of Terms. Part 1 of Summa Logicae. Transl. J. Loux. Notre Dame - London : University of Notre Dame Press.

Ockham, V., 2009, Summa logicae. Přel. R. Nemec. In: CHABADA, M. (ed.) Antológia Patristika - Scholastika. Vybrané kapitoly. Teologická fakulta Trnavskej univerzity, s. 422-459.

Beckmann,P.J., 1981, „Scientia proprie dicta“. In: Sprache und Erkenntnis Im Mittelalter. Berlin - New York : Walter de Gruyter, s . 637-647.

Ghisalberti, A., 1976, Introduzione a Ockham. Roma - Bari : Editori Laterza.

Goddu, A., 1990, The Dialectic of Certitude and Demonstrability among Fourteenth-Century Ockhamists. In: Knuuttila S. (e. a.) Knowledge and the Sciencies in Medieval Philosophy. Vol. II. Helsinky : Luther Agricola Society

Honnefelder, L., 2009, Viliam Ockham. Potenciálnost' metafyziky. In: CHABADA, M. (ed.) : Antológia Patristika - Scholastika. Prel. R. Nemec, Teologická fakulta Trnavskej univerzity : Dobrá kniha, s. 406421. 
Lagerlund, H. (ed.), 2011, Encyclopedia of medieval philosophy. Philosophy between 500 and 1500. London: Springer.

Leppin, V., 2005, Gotteslehre und Logik bei Wilhelm Ockham. In: PERLER, D. (ed.): Logik und Theologie. Das Organon im arabischen und lateinischen Mittelalter. Leiden - Boston : Brill, s. 429-446.

Marrone, S. P., 2001, The Light of Thy Countenance. Science and Knowledge of God in the Thirteenth Century. 2. vol. Leiden - Boston Köln : Brill.

Moody, E. 1935, Logic of William of Ockham. New York : Russell and Russell.

Ockham, G., 1974, Summa Logicae. (= SL)P. Boehner, G. Gál (eds.) In: Opera Philosophica. I. St. Bonaventure, NY: The Franciscan Institute.

Ockham, G., 1967, In Librum Primum Sententiarum Ordinatio, G. Etzkorn, F. Kelley (eds.) Opera Theologica (OTh). zv. III., New York: St. Bonaventure, The Franciscan Institute.

Ockham, G., 1985, Expositio in libros Physicorum Aristotelis. Prologus et Libri I-III. OPh IV. Richter V. (ed.) New York : St. Bonaventure.

Pasnau, R., 2010, Scientia and Certainty. In: PASNAU, R.(ed.)The Cambridge history of medieval philosophy. Vol. 1., Cambridge University Press, s. 357-368.

Ritter, J. (ed.), 1971, Historisches Wörterbuch der Philosophie 1. Basel : Schwabe. 